\title{
Article \\ Genome-Wide Analysis for Early Growth-Related Traits of the Locally Adapted Egyptian Barki Sheep
}

\author{
Ibrahim Abousoliman ${ }^{1,2}$, Henry Reyer ${ }^{1}\left(\mathbb{D}\right.$, Michael Oster $^{1}{ }^{(D}$, Eduard Murani $^{1}\left(\mathbb{D}\right.$, Ismail Mohamed $^{2}$ \\ and Klaus Wimmers $1,3, *$ (D) \\ 1 Leibniz Institute for Farm Animal Biology, Wilhelm-Stahl-Allee 2, 18196 Dummerstorf, Germany; \\ abou-soliman@fbn-dummerstorf.de (I.A.); reyer@fbn-dummerstorf.de (H.R.); \\ oster@fbn-dummerstorf.de (M.O.); murani@fbn-dummerstorf.de (E.M.) \\ 2 Desert Research Center, Department of Animal and Poultry Breeding, 1 Mathaf El-Matareya St., \\ El-Matareya, Cairo 11753, Egypt; ssmm_ismail@yahoo.com \\ 3 Faculty of Agricultural and Environmental Sciences, University of Rostock, Justus-von-Liebig-Weg 7, \\ 18059 Rostock, Germany \\ * Correspondence: wimmers@fbn-dummerstorf.de; Tel.: +49-382-08-68-600
}

Citation: Abousoliman, I.; Reyer, H.; Oster, M.; Murani, E.; Mohamed, I.; Wimmers, K. Genome-Wide Analysis for Early Growth-Related Traits of the Locally Adapted Egyptian Barki

Sheep. Genes 2021, 12, 1243.

https://doi.org/10.3390/

genes12081243

Academic Editor: Emilia Bagnicka

Received: 17 June 2021

Accepted: 11 August 2021

Published: 13 August 2021

Publisher's Note: MDPI stays neutral with regard to jurisdictional claims in published maps and institutional affiliations.

Copyright: () 2021 by the authors. Licensee MDPI, Basel, Switzerland. This article is an open access article distributed under the terms and conditions of the Creative Commons Attribution (CC BY) license (https:// creativecommons.org/licenses/by/ $4.0 /)$.

\begin{abstract}
Sheep play a critical role in the agricultural and livestock sector in Egypt. For sheep meat production, growth traits such as birth and weaning weights are very important and determine the supply and income of local farmers. The Barki sheep originates from the northeastern coastal zone of Africa, and due to its good adaptation to the harsh environmental conditions, it contributes significantly to the meat production in these semi-arid regions. This study aimed to use a genomewide SNP panel to identify genomic regions that are diversified between groups of individuals of Egyptian Barki sheep with high and low growth performance traits. In this context, from a phenotyped population of 140 lambs of Barki sheep, 69 lambs were considered for a genome-wide scan with the Illumina OvineSNP50 V2 BeadChip. The selected lambs were grouped into divergent subsets with significantly different performance for birth weight and weaning weight. After quality control, 63 animals and 40,383 SNPs were used for analysis. The fixation index $\left(F_{S T}\right)$ for each SNP was calculated between the groups. The results verified genomic regions harboring some previously proposed candidate genes for traits related to body growth, i.e., EYA2, GDF2, GDF10, MEF2B, SLC16A7, TBX15, TFAP2B, and TNNC2. Moreover, novel candidate genes were proposed with known functional implications on growth processes such as CPXM2 and LRIG3. Subsequent association analysis showed significant effects of the considered SNPs on birth and weaning weights. Results highlight the genetic diversity associated with performance traits and thus the potential to improve growth traits in the Barki sheep breed.
\end{abstract}

Keywords: Barki sheep; growth; birth weight; weaning weight; indigenous sheep; lamb; SNP chip

\section{Introduction}

Breeding is one of the main drivers affecting allele frequencies, leading to genomic regions with genetic differentiation, thus contributing to the genetic diversity of livestock species [1]. Many studies analyzing the genetic architecture of complex traits using genomewide SNP data have been conducted in different livestock species in the last decade. In ruminants, these studies have detected candidate genes related to growth, muscle conformation, adaptation, and reproduction traits in sheep [2-6]; milk production, reproduction, body constitution, muscle development, coat color, and thermotolerance in cattle [7,8]; and adaptation, coat color, milk composition, and growth traits in goats $[9,10]$. To identify the corresponding genomic regions, several methods are available that are capable of analyzing genetic variation within a population and between populations or groups of individuals. The calculation of fixation index $\left(F_{S T}\right)$ of Weir and Cockerham (1984) is one of the most popular methods to analyze population structure in this framework. The $F_{S T}$ approach 
measures genomic differentiation between two or more populations, breeds, or divergent lines and subgroups in the same breed, depending on allele frequency, and is thus able to identify highly differentiated alleles that undergo selection, while being unbiased for sample size $[7,11]$.

Growth traits are very important in sheep breeding and considerably affect the resource efficiency and breeder's profit. Growth traits, like other quantitative traits, are controlled by the complex genetic background of the animal as well as environmental factors, such as feed and herd management. Body weight gain has a moderate to high heritability [12-14] and is one of the main indices of selection, especially for meat type breeds. However, it also influences wool production and the reproduction performance of sheep [15]. Body weight gain can be monitored at birth or at other animal life stages and largely determines the amount of income from sheep meat production. Weight measurement at birth represents the earliest indicator of growth performance and related traits [16]. Various genetic but also non-genetic factors affect the birth weight, such as the dam's weight, age, and nutrient supply during pregnancy [17]. The heritability of birth weight was estimated to be 0.39 and 0.31 in Iranian Mehraban and Lori-Bakhtiari sheep breeds, respectively. For weaning weight, heritability was estimated to be 0.25 for weaning weight in Iranian Mehraban sheep [17]. Heritabilities for birth weight and weaning weight were 0.19 and 0.20 in Barki sheep, respectively [18]. For Barki sheep-breeding in particular, high weight at birth is not a primary goal; more importance is given to achieving higher weaning weights [18]. This is also related to the fact that problems for the dam or the newborn lamb should be avoided, such as dystocia during the birth process. In fact, Barki sheep show large differences in growth traits, ranging from 2.4 to $5.0 \mathrm{~kg}$ for birth weight with an average of $3.7 \mathrm{~kg}$ and from 5.2 to $28.8 \mathrm{~kg}$ for weaning weight with an average of $13.8 \mathrm{~kg}$ [19]. In general, although Barki sheep are highly adapted to the harsh environmental conditions of northeast Africa and have a high value for farmers in this region, it remains difficult to obtain a large number of genotyped and comprehensively phenotyped animals due to the smallholder sheep farming systems in Egypt [20]. Improving growth traits in sheep using genetics is promising and is being implemented in different sheep populations but would further benefit from an understanding of the underlying biological processes and functions. The aim of the current study was to gain insight into diversified genomic regions for growth traits in the Barki sheep breed and to derive potential candidate genes that are functionally related to the traits of interest.

\section{Materials and Methods}

\subsection{Animals and Phenotypes}

In this study, a population of 140 lambs (55 males and 85 females) from single births of the Egyptian Barki sheep was considered for investigation of the genomic regions and candidate genes for growth traits comprising birth weight and weaning weight. Animals were raised in the farms of the Desert Research Centre (DRC), Ministry of Agriculture, Egypt. They were kept under an intensive breeding system in semi-open yards. The lambs were from one breeding season and were offspring of 10 rams. Birth weight within $12 \mathrm{~h}$ after parturition and weaning weight after a lactation period of 3 months (90 days) were recorded for every lamb using an electronic scale. From birth to weaning age, the lambs were suckled only on their mother's milk daily. Fresh water was offered two times daily to lambs ad libitum. The experiment was conducted in accordance with all ethics and animal rights (DRC), considering all regulations in conformity with the European Union Directive for the protection of experimental animals (2010/63/EU).

\subsection{Genotyping and Quality Control}

For each lamb, blood was sampled from the jugular vein in EDTA-containing tubes and stored at $-80{ }^{\circ} \mathrm{C}$ until DNA extraction. DNA extraction was performed according to the manufacturer's instructions with the G-spin Total DNA Extraction kit (iNtRON Biotechnology, Seoul, Korea). Out of the entire population of 140 animals, 69 lambs with 
considerable differences in the respective growth trait were genotyped using the Illumina OvineSNP50 V2 BeadChip (Illumina, San Diego, CA, USA). The relative identity-by-descent (IBD) was calculated for all pairs of lambs. The genetic relatedness average was 0.15 . The iScan Reader (Illumina) was used to image the raw signal intensities of the 53,516 SNPs on the chip, which were subsequently converted into genotypes with the GenomeStudio software (version 2.0). The samples with call rates $<90 \%$ were removed from further analysis. The SNPs with genotype call rates $<98 \%$, minor allele frequencies (MAF) $<0.05$, in high linkage disequilibrium $\left(\mathrm{r}^{2}>0.5\right)$ within windows of 50 SNPs, and significant deviation from Hardy-Weinberg equilibrium at $p<10^{-6}$ were removed from the analysis. JMP Genomics software (version 9) was used for quality control. A total of 63 animals and 40,383 SNPs remained and passed the quality control. Base pair positions and names of SNP markers were updated to the latest version of the ovine genome (Oar_v3.1 accessed on 6 July 2020). SNPs not located on autosomes and lacking reference SNP (rs) identifiers were excluded. Based on the SNP data, the genomic relationship matrix of lambs was calculated using SNPRelate R package (version 1.24.0) and visualized in a principal component plot (Supplementary Materials Figure S1).

\section{3. $F_{S T}$ Analysis and Screening for Candidate Genes}

For each of the traits, birth weight and weaning weight, the genotyped animals were divided into two subgroups, each representing the extreme phenotypes for the respective trait with significant differences between the groups (Figure 1). The Student's $t$-test was used to compute the differences between the means of high and low groups. The fixation index $\left(F_{S T}\right)$ for each SNP was calculated between the groups low birth weight (LBW) - high birth weight (HBW) and low weaning weight (LWW) - high weaning weight (HWW) by the SNPRelate R package (version 1.24.0) using the Weir and Cockerham method [21,22]. $F_{S T}$ values were Z-transformed using the following equation $Z\left(F_{S T}\right)=\left(F_{S T}-\mu F_{S T}\right) / 6 F_{S T}$, where $\mu F_{S T}$ is the overall mean of $F_{S T}$ values and $6 F_{S T}$ is the standard deviation of $F_{S T}$ values. In addition, an SNP-specific baseline $F_{S T}$ estimate was calculated to evaluate the results of the $F_{S T}$ analysis. This estimation was based on a random permutation of the group assignment with 10,000 iterations. Subsequently, the distribution of SNP-specific $F_{S T}$ values was used to calculate permutation-based $p$-values for the intended group comparisons (LBW-HBW and LWW-HWW) using the statmod R package [23]. Using the genomic inflation factor lambda $(\lambda \mathrm{BW}=1.19, \lambda \mathrm{WW}=1.72)$, genomic control corrections were made and permutation $p$-values were adjusted. Only the SNPs having the top $0.05 \%$ of $Z\left(F_{S T}\right)$ values were selected for further analysis. Manhattan plots of $Z\left(F_{S T}\right)$ value for each SNP were constructed using qqman package (version 0.1.4) in R software. To identify the candidate genes, the Ensembl database was used to select the genes within $2 \mathrm{Mb}$ windows around high $Z\left(F_{S T}\right)$ SNPs [24]. Genes harboring a highlighted $Z\left(F_{S T}\right)$ SNP were considered as positional candidate genes. Functional candidate genes in the respective genomic region were identified according to their functional relation with the phenotypes, employing available gene annotations from the GeneCards (http:/ / www.genecards.org; accessed on 19 May 2021) and Uniprot (http:/ / www.uniprot.org; accessed on 19 May 2021) databases. Kyoto Encyclopedia of Genes and Genomes (KEGG, https: / /www.kegg.jp/; accessed on 23 July 2021) pathway enrichment analysis of the functional, positional, and closest upand downstream-located genes based on SNPs that exceeded the threshold was performed using ClueGO plugin with the Cytoscape software (version 3.6.1) [25,26]. 


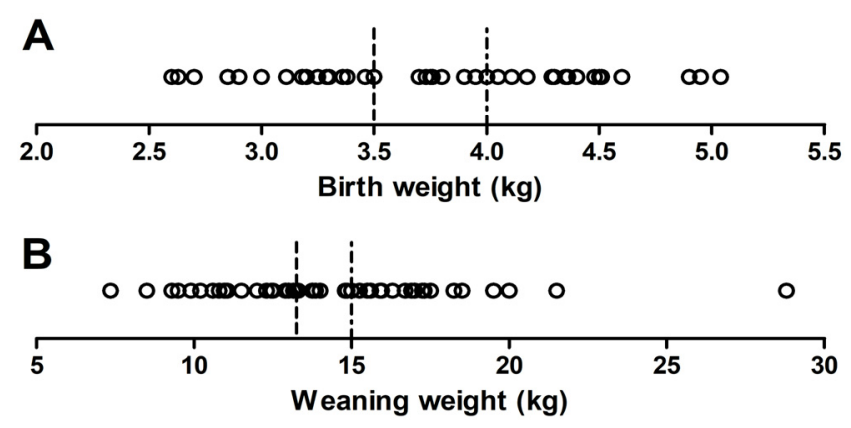

Figure 1. Distribution of lambs according to their birth weight (A) and weaning weight (B). The dashed lines indicate the thresholds for classification of animals into low and high groups.

\subsection{Marker-Trait Association Analysis}

The association analysis was carried out to test the effect of the genotypes of the selected SNPs on the phenotypes of birth and weaning weight by JMP Genomics software (version 9) using the QK mixed model procedure considering the genomic relationship matrix. In addition, the statistical model included the sex of lamb as fixed effect (two levels). $p \leq 0.05$ was considered significant, $p \leq 0.01$ highly significant, and $p>0.05$ not significant.

\section{Results}

\subsection{Phenotypic Data of Growth Traits}

Descriptive statistics of birth weight and weaning weight of Barki lambs with divergent performance in the respective trait are shown in Table 1.

Table 1. Descriptive statistics of lamb growth traits.

\begin{tabular}{ccccccccc}
\hline Trait & Abbreviation & Group & N & Mean & SD & Min & Max & $p$-Value \\
\hline \multirow{2}{*}{ Birth weight $(\mathrm{kg})$} & \multirow{2}{*}{ BW } & HBW & 31 & 4.3 & 0.3 & 4.0 & 5.0 & $p<0.001$ \\
\multirow{2}{*}{ Weaning weight $(\mathrm{kg})$} & \multirow{2}{*}{ WW } & LBW & 24 & 3.2 & 0.3 & 2.6 & 3.5 & \multirow{2}{*}{0} \\
& & HWW & 28 & 18.1 & 2.5 & 15.0 & 28.8 & $p<0.001$ \\
\hline
\end{tabular}

${ }^{*} \mathrm{HBW}=$ High birth weight, LBW = Low birth weight, $\mathrm{HWW}=$ High weaning weight, $\mathrm{LWW}=$ Low weaning weight. ${ }^{* *}=p$-value computed using $t$-test, $\mathrm{SD}=$ Standard deviation.

\subsection{Detection of Genomic Regions and Candidate Genes}

For the detection of genomic regions and candidate genes of growth traits, subgroups with distinct differences in the respective traits were analyzed. In particular, $\mathrm{Z}\left(F_{S T}\right)$ values were calculated to explore genomic differences between groups using genome-wide distributed SNPs. Figure 2 shows a Manhattan plot of SNP-specific $Z\left(F_{S T}\right)$ values for birth weight and highlighted genomic regions and SNPs with the highest $Z\left(F_{S T}\right)$ values. Obtained SNPs and regions were distributed on chromosomes 1, 2, 3, 5, 6, 8, 13, 14, 16, 17, $19,22,23,24$, and 25 (cutoff $Z\left(F_{S T}\right) \geq 7.68$, Table 2 ). Genomic regions highlighted by the selected SNPs were mined for positional and functional candidate genes (Table 2). This analysis yielded eight positional candidate genes comprising PCKS5, WDR35, LAMA5, HYDIN, FAM160A1, GPR26, PTPRM, and DNAH3. Moreover, a total of 13 functional candidate genes in the indicated genomic regions were identified, which are known to affect birth weight or are involved in the development process during the embryonic stage and after birth. These comprise TBX15, SLC16A7, LRIG3, MATN3, OSR1, CITED2, LAMA5, URI1, SUCLG2, CPXM2, LAMA1, GDF2, and GDF10. Among the vital processes to which these genes contribute is the development of body organs, such as limbs, liver, lungs, brain, skeletal system, and muscles. Except for the SNPs indicating the genomic regions harboring BRINP1, CITED2, CPXM2, GDF2, and GDF10, the marker-trait association analysis confirmed a significant relationship of the candidate loci with birth weight in the Barki lamb population (Table 2, Supplementary Materials Table S1). 


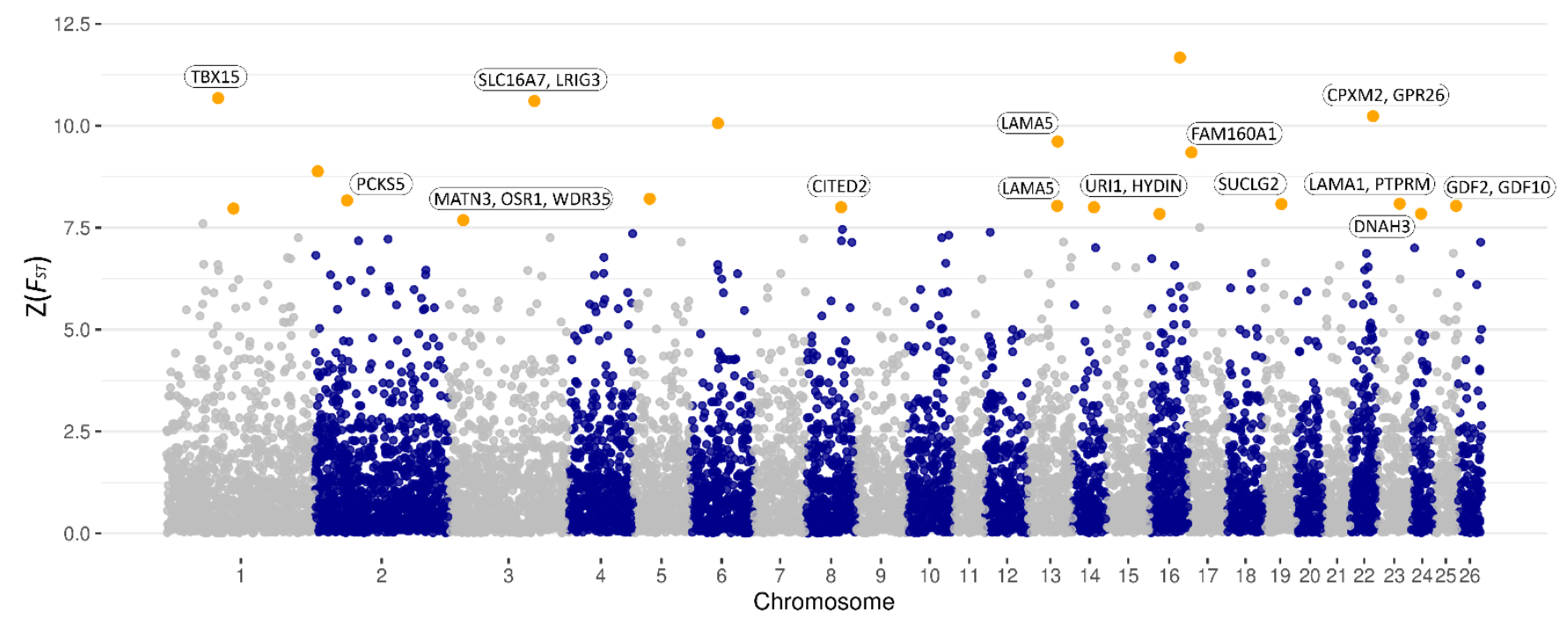

Figure 2. Manhattan plot of the $\mathrm{Z}\left(F_{S T}\right)$ values for each single nucleotide polymorphism (SNP) between Barki sheep groups divergent in birth weight (LBW-HBW). Orange dots represent SNPs that passed the cutoff threshold at $99.95 \%$ of the percentile distribution $\left(Z\left(F_{S T}\right) \geq 7.68\right)$.

Table 2. Genomic positions of SNPs that exceeded the cutoff threshold $\left(\mathrm{Z}\left(F_{\mathrm{ST}}\right) \geq 7.68\right)$ for divergence in birth weight and adjacent candidate genes within a $2 \mathrm{Mb}$ window.

\begin{tabular}{|c|c|c|c|c|c|c|c|}
\hline Rs Identifier & Chr & Position & MAF & $\mathrm{Z}\left(F_{\mathrm{ST}}\right)$ & $\begin{array}{l}\text { Permutation } \\
p \text { Value }^{1}\end{array}$ & $\begin{array}{c}\text { Association } \\
p \text { Value }^{2}\end{array}$ & Candidate Genes ${ }^{3}$ \\
\hline rs426652102 & 1 & 95369397 & 0.335 & 10.68 & 0.0006 & 0.004 & TBX15, SPAG17 \\
\hline rs409727057 & 1 & 124117118 & 0.220 & 7.97 & 0.001 & 0.003 & CLDN17, GRIK1 \\
\hline rs423222301 & 2 & 5472326 & 0.301 & 8.88 & 0.0006 & 0.015 & BRINP1, TLR4 \\
\hline rs419514091 & 2 & 60044110 & 0.369 & 8.17 & 0.0006 & 0.116 & PCKS5, RFK, ENSOARG00000012533 \\
\hline rs428614465 & 3 & 27732721 & 0.492 & 7.68 & 0.0009 & $<0.0001$ & MATN3, OSR1, WDR35, TTC32 \\
\hline rs417060060 & 3 & 160252310 & 0.446 & 10.61 & 0.0003 & 0.001 & SLC16A7, LRIG3 \\
\hline rs413547561 & 5 & 31477570 & 0.481 & 8.21 & 0.001 & 0.144 & PRR16, FAM170A \\
\hline rs413364871 & 6 & 51650705 & 0.301 & 10.06 & 0.0003 & 0.006 & - \\
\hline rs427385309 & 8 & 64075259 & 0.276 & 8.00 & 0.0006 & 0.156 & CITED2, U5, NMBR \\
\hline rs406649973 & 13 & 54940415 & 0.444 & 9.61 & 0.0003 & 0.041 & LAMA5, CDH28, CDH4 \\
\hline rs419112095 & 13 & 54219758 & 0.295 & 8.03 & 0.0009 & 0.166 & LAMA5, RPS21, ADRM1 \\
\hline rs410323459 & 14 & 39415649 & 0.328 & 8.00 & 0.001 & 0.0006 & URI1, HYDIN, CMTR2, POP4 \\
\hline rs 423237115 & 16 & 56144068 & 0.412 & 11.67 & 0.0003 & 0.014 & MYO10 \\
\hline rs413049228 & 16 & 18186560 & 0.134 & 7.84 & 0.009 & 0.058 & ZSWIM6, SMIM15 \\
\hline rs413966946 & 17 & 6026379 & 0.465 & 9.34 & 0.0006 & 0.006 & FAM160A1, GATB, SH3D19 \\
\hline rs430430903 & 19 & 33088813 & 0.289 & 8.08 & 0.0006 & 0.046 & SUCLG2, ENSOARG00000010424 \\
\hline rs417719085 & 22 & 42323039 & 0.444 & 10.23 & 0.0003 & 0.002 & CPXM2, GPR26, ACADSB \\
\hline rs412781362 & 23 & 41177245 & 0.127 & 8.07 & 0.0009 & 0.001 & LAMA1, PTPRM, RAB12 \\
\hline rs421209784 & 24 & 18748352 & 0.086 & 7.84 & 0.0009 & 0.001 & DNAH3, LYRM1, TMEM159 \\
\hline rs429736586 & 25 & 41911462 & 0.348 & 8.03 & 0.0003 & 0.064 & GDF2, GDF10, PTPN20 \\
\hline
\end{tabular}

${ }^{1} p$-value resulting from permutation-based test of $F_{S T}$ values and subsequent adjustment for genomic inflation; ${ }^{2} p$-value resulting from association analysis of the respective SNP with birth weight; ${ }^{3}$ Gene names in bold $=$ functional candidate genes, underlined $=$ positional candidate genes, only italic = closest up- and downstream-located genes within a $2 \mathrm{Mb}$ window, $\mathrm{Chr}=$ chromosome, $\mathrm{MAF}=$ minor allele frequency, $Z\left(F_{S T}\right)=\mathrm{SNP}$-specific Z-transformed fixation index.

For weaning weight, 20 SNPs, which reached the threshold $Z\left(F_{S T}\right)$ value at $99.95 \%$ of the percentile distribution, were identified (cutoff $Z\left(F_{S T}\right) \geq 6.99$, Table 3). These SNPs indicated 13 genomic regions distributed on chromosomes 1, 2, 3, 5, 6, 10, 12, 13, 15, 18, 20, 22, and 25, as illustrated in Figure 3. Considering these regions, seven positional candidate genes, directly tagged by one of the identified SNPs, were detected. These genes are ASB3, SOX5, TP53RK, DGKZ, FBLN5, PCDH15, and GLUD1. Moreover, 19 functional candidate genes were identified in the respective genomic regions for weaning weight including MEGF9, PTPRU, FABP3, MEF2B, HAPLN4, NCAN, WNT9A, WNT3A, POSTN, EYA2, MMP9, TNNC2, ACP2, LRP4, FBLN5, TFAP2B, BMPR1A, GDF2, and GDF10. Considering the SNPs indicative for these candidate genes, most of the SNPs appeared to be 
significantly associated with weaning weight (Table 3, Supplementary Materials Table S2). Considering all SNPs that exceeded the threshold for birth and weaning weights, results of the enrichment analysis of the functional, positional, and closest up- and downstream located genes within $2 \mathrm{Mb}$ are presented (Supplementary Materials Figure S2).

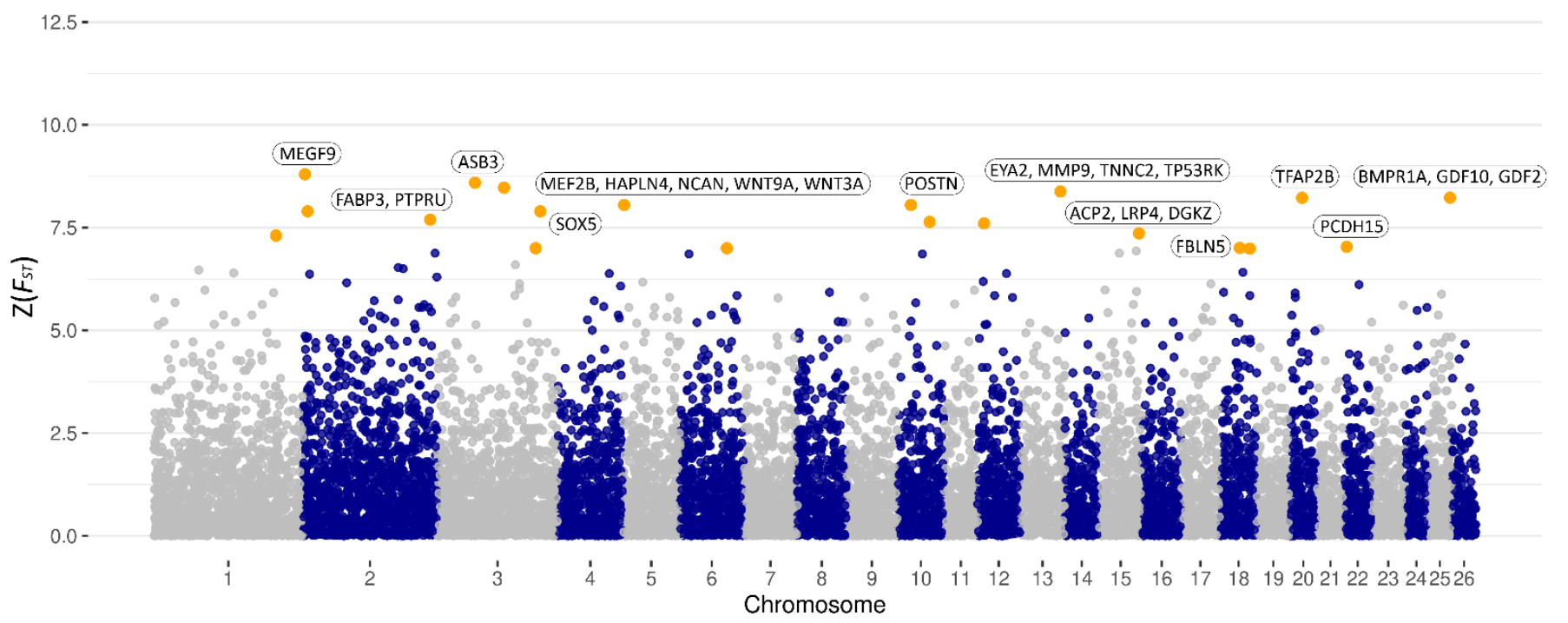

Figure 3. Manhattan plot of the $\mathrm{Z}\left(F_{S T}\right)$ values for each single nucleotide polymorphism (SNP) of weaning weight. Orange dots represent SNPs that passed the cutoff threshold at $99.95 \%$ of the percentile distribution $\left(\mathrm{Z}\left(F_{S T}\right) \geq 6.99\right)$.

Table 3. Genomic positions of SNPs that exceeded the cutoff threshold $\left(\mathrm{Z}\left(F_{\mathrm{ST}}\right) \geq 6.99\right)$ for divergence in weaning weight and adjacent candidate genes within a $2 \mathrm{Mb}$ window.

\begin{tabular}{|c|c|c|c|c|c|c|c|}
\hline Rs Name & Chr & Position & MAF & $\mathrm{Z}\left(F_{\mathrm{ST}}\right)$ & $\begin{array}{l}\text { Permutation } \\
p \text {-Value }\end{array}$ & $\begin{array}{l}\text { Association } \\
p \text {-Value }^{2}\end{array}$ & Candidate Genes ${ }^{3}$ \\
\hline rs401497638 & 1 & 226047403 & 0.274 & 7.30 & 0.170 & 0.002 & IL12A, IQCJ \\
\hline rs402362274 & 2 & 4014386 & 0.194 & 8.80 & 0.003 & 0.015 & MEGF9, CDK5RAP2, BRINP1 \\
\hline rs427650461 & 2 & 8985061 & 0.259 & 7.90 & 0.003 & 0.018 & TNFSF15, TMEM268 \\
\hline rs405054059 & 2 & 236085906 & 0.354 & 7.69 & 0.004 & 0.177 & FABP3, MATN1, PTPRU \\
\hline rs420573745 & 3 & 70227376 & 0.500 & 8.59 & 0.003 & 0.077 & $\underline{A S B 3}, \mathrm{CHAC2}$ \\
\hline rs422502823 & 3 & 124010853 & 0.408 & 8.47 & 0.003 & 0.039 & $M G A T 4 C, C 12$ orf50 \\
\hline rs425747978 & 3 & 191139722 & 0.269 & 7.90 & 0.003 & 0.067 & SOX5, BCAT1, ETNK1 \\
\hline rs410754805 & 3 & 182669294 & 0.341 & 7.00 & 0.003 & 0.044 & RESF1, AMN1 \\
\hline rs429678680 & 5 & 3076397 & 0.224 & 8.10 & 0.003 & 0.278 & $\begin{array}{c}\text { MEF2B, HAPLN4, NCAN, WNT9A, WNT3A, } \\
\text { PRSS38, SNAP47 }\end{array}$ \\
\hline rs418926568 & 6 & 86505675 & 0.381 & 7.00 & 0.004 & 0.120 & SLC4A4, GC \\
\hline rs401888979 & 10 & 25115607 & 0.219 & 8.10 & 0.003 & 0.002 & POSTN, RFXAP, SERTM1 \\
\hline rs428497629 & 10 & 59974520 & 0.263 & 7.64 & 0.004 & 0.006 & SLITRK1, SLITRK6 \\
\hline rs426943634 & 12 & 12266633 & 0.436 & 7.60 & 0.003 & 0.009 & RGS18, BRINP3 \\
\hline rs413169429 & 13 & 74924747 & 0.303 & 8.38 & 0.003 & 0.009 & $\begin{array}{c}\text { EYA2, MMP9, TNNC2, TP53RK } \\
\text { SLC2A10 }\end{array}$ \\
\hline rs411451096 & 15 & 74597812 & 0.399 & 7.36 & 0.003 & 0.128 & ACP2, LRP4, DGKZ, CREB3L1, MDK \\
\hline rs430684800 & 18 & 36936501 & 0.322 & 7.01 & 0.003 & 0.009 & NOVA1, FOXG1 \\
\hline rs426036565 & 18 & 55537048 & 0.414 & 6.99 & 0.003 & 0.495 & FBLN5, TC2N, TRIP11 \\
\hline rs410079568 & 20 & 23394498 & 0.470 & 8.23 & 0.003 & 0.143 & TFAP2B, PKHD1 \\
\hline rs421690996 & 22 & 5090223 & 0.345 & 7.03 & 0.003 & 0.026 & PCDH15, U3, SYCE1 \\
\hline rs400432841 & 25 & 41241866 & 0.459 & 8.23 & 0.003 & 0.039 & BMPR1A, GDF10, GDF2, GLUD1, U6, SHLD2 \\
\hline
\end{tabular}

${ }^{1} p$-value resulting from permutation-based test of $F_{S T}$ values and subsequent adjustment for genomic inflation; ${ }^{2} p$-value resulting from association analysis of the respective SNP with weaning weight; ${ }^{3}$ Gene names in bold $=$ functional candidate genes, underlined = positional candidate genes, only italics = closest up- and downstream-located genes within a $2 \mathrm{Mb}$ window, $\mathrm{Chr}=$ chromosome, $\mathrm{MAF}=$ minor allele frequency, $\mathrm{Z}\left(F_{\mathrm{ST}}\right)$ = SNP-specific Z-transformed fixation index.

\section{Discussion}

In this study, we used the Ovine SNP50 V2 BeadChip to identify the genomic differences between groups of Barki sheep that differed significantly in growth traits (birth and weaning weight). The average birth weight of Barki lambs was similar to those of 
lambs of the native Egyptian breeds, such as Rahmani and Ossimi breeds, with 3.73 and $3.9 \mathrm{~kg}$. However, in terms of weaning weight, Rahmani and Ossimi lambs are slightly heavier than Barki lambs with average weights of 17.63 and $14.05 \mathrm{~kg}$, respectively $[27,28]$. Moreover, birth weight $(5.08 \mathrm{~kg})$ and weaning weight $(29.8 \mathrm{~kg})$ of Romney lambs, as one of the worldwide economically important meat-type breeds, were reported to be higher than the weights of Barki sheep [29]. In order to elucidate genetic contributions, genetic differentiations between the subgroups were investigated by the calculation of SNP-specific Z $\left(F_{S T}\right)$ values. Considering birth weight and weaning weight, identified genomic regions on chromosomes 2, 3, 5, 15, 16, 18, 22, 24, and 25 were previously proposed in the sheep QTL database to be associated with some growth traits such as body weight at different ages of lambs and average daily gain [30]. A total of 15 genomic regions were found to exhibit divergent allele frequencies for birth weight in Barki lambs. Regions on chromosomes 1, 3, and 16 are proposed to be the most promising regions, since they enclose four SNPs with the highest $Z\left(F_{S T}\right)$ values. Within the genomic region on chromosome 1 at $95.3 \mathrm{Mb}$, T-box 15 (Tbx15) appears to be the most promising functional candidate gene. Tbx15 gene is a member of T-box gene family, which encodes for transcription factors. T-box genes play a critical role in the development of different tissues and organs in vertebrates and invertebrates, such as the skeletal system during the embryonic stage [31]. The expression of Tbx15 was reported in the development of forelimb and hind limb buds in chick and mouse [32,33]. Within chromosome 3, the solute carrier family 16 member 7 (SLC16A7) gene at $159.6 \mathrm{Mb}$ and the leucine-rich repeats and immunoglobulin-like domains protein 3 (LRIG3) gene at $160.4 \mathrm{Mb}$ were proposed as additional promising candidates for birth weight. SLC16A7 was reported to have a role in skeletal muscle as a lactate cotransporter [34]. LRIG3 is known to be involved in placenta and embryonic development in pigs [35]. Moreover, the carboxypeptidase-like protein $\mathrm{X} 2$ encoding gene (CPXM2) located on chromosome 22 at $42.4 \mathrm{Mb}$ plays an important role in growth processes. It was reported to be one of the genes that regulate backfat thickness at different life stages in pigs [36].

Within the genomic region on chromosome 5 at $3.1 \mathrm{Mb}$, the myocyte enhancer factor$2 \mathrm{~B}(M E F 2 B)$ gene was proposed as a functional gene for weaning weight. This gene encodes a member of the myocyte enhancer factor-2 family (MEF2A, MEF2B, MEF2C, and MEF2D), which plays an important and critical role in cell development, embryonic development, muscle tissue growth, and development processes [37,38]. Polymorphism in the $3^{\prime}$-UTR of the $M E F 2 B$ gene showed a significant correlation with some growth traits in New Ujumqin Sheep such as body weight and chest girth at 4 and 6 months [39]. Previous studies revealed a significant association between $M E F 2 B$ and skeletal muscle satellite cell and reproductive traits in pigs [40] as well as diameter of muscle fibers in goats [41]. The SNP indicating the $M E F 2 B$ region was found to be significantly associated with weaning weight. Within chromosome 13, the eyes absent homolog 2 (EYA2) and the fast skeletal muscle troponin C (TNNC2) genes were revealed as candidates for weaning weight. In Ethiopian sheep, EYA2 was proposed as a candidate for embryonic development of tendons, bones, and cartilages [42]. TNNC2 plays a critical role in skeletal muscle contraction, modulates the $\mathrm{Ca} 2+-$ activation characteristics of muscle fibers [43], and is highly expressed during the myoblast differentiation and skeletal muscle development [44]. Previous studies on TNNC2 reported a significant association with growth traits in porcine skeletal muscles [45] and with carcass weight and marbling score in three native sheep breeds [46].

Within the region on chromosome 20 at $23.4 \mathrm{Mb}$, the transcription factor AP-2B (TFAP2B) gene was proposed as a functional candidate for weaning weight. TFAP2B was documented in vertebrates and invertebrates and has a critical role during embryonic development [47]. The function of TFAP2B in the development of craniofacial structures, limb formation, and kidney and skin development was reported in mice [48].

Based on the indicated genomic regions of birth weight and weaning weight, some functional candidate genes were proposed such as growth differentiation factors 2 and 10 genes (GDF2, GDF10) on chromosome 25. GDF2 and GDF10 are members of the transforming growth factor- $\beta$ (TGF- $\beta$ ) superfamily and the bone morphogenetic protein 
family (BMP), also known as bone morphogenetic protein 9 and 3B (BMP9, BMP3B) [49]. Previous studies reported a significant correlation between GDF2 and GDF10 genes and weaning weight in New Zealand dual-purpose sheep [50]. GDF10 regulates cell growth and differentiation in embryonic and adult tissues. Genetic polymorphism in the bovine GDF10 gene showed a significant effect on some body measurements in Chinese indigenous cattle [51]. Results of the marker-trait association analysis confirmed the significant effect of the majority of selected SNPs on both birth weight and weaning weight and reflected the contribution of these SNPs to the phenotypic differences between high and low groups of these traits. Results of the enrichment analysis revealed the contribution of the selected genes in some physiological pathways related to growth performance such as animal organ formation, regulation of embryonic development, and skeletal muscle development, which confirm the critical role of these genes in growth processes. However, the robustness of association analysis is a matter of sample size [52]; the results of this study require validation in an independent population and with a larger sample size.

\section{Conclusions}

The genome-wide SNPs analysis revealed a number of genomic regions containing putative QTL for birth weight and weaning weight. The QTL regions cover a number of promising functional candidate genes such as CPXM2, EYA2, GDF2, GDF10, LRIG3, MEF2B, SLC16A7, TBX15, TFAP2B, and TNNC2, which deserve further investigation, due to their relation to biological processes, including metabolism, body growth, organ morphogenesis, skeletal muscle development, and cell proliferation and differentiation. Moreover, the marker-trait association analysis revealed a significant relationship of the considered SNPs to the studied traits. Our findings provide valuable information for a better understanding of the genetics of early growth-related traits and might contribute to the improvement of these traits in the Barki sheep breed.

Supplementary Materials: The following tables are available online at https://www.mdpi.com/ article/10.3390/genes12081243/s1. Table S1: Association of selected SNP genotypes with birth weight in Egyptian Barki lambs (Mean \pm SE); Table S2: Association of selected SNP genotypes with weaning weight in Egyptian Barki lambs (Mean \pm SE); Figure S1: Principal component plot of the genomic relationship of animals displaying the classification into high and low groups for birth weight (frame color) and weaning weight (fill color); Figure S2: KEGG pathway enrichment analysis of the functional, positional, and closest up- and downstream located genes within a $2 \mathrm{Mb}$ window.

Author Contributions: Conceptualization, I.M. and K.W.; methodology, I.A., H.R. and E.M.; formal analysis, I.A., H.R. and M.O.; resources, I.M. and K.W.; data curation, I.A. and H.R.; writingoriginal draft preparation, I.A.; writing - review and editing, all authors; supervision, H.R. and K.W.; funding acquisition, I.M. and K.W. All authors have read and agreed to the published version of the manuscript.

Funding: This work was supported by a grant to I.A. from the Sector for Missions and Cultural Affairs, Ministry of Higher Education, Egypt, and co-financed by the Leibniz Institute for Farm Animal Biology (FBN), Germany.

Institutional Review Board Statement: All animal handling procedures and samples collection were conducted with the approval of the Department of Animal Health (DRC) Committee, did not require an animal experimentation permit according to the regulations of the Desert Research Center (DCR) Ethics Board, and complied in their implementation with the European Union Directive on the Protection of the Experimental Animals (2010/63/EU).

Data Availability Statement: Genotypic and phenotypic information has been deposited at Open Science Framework (https:/ / osf.io/ qj29r/; accessed on 19 November 2020).

Acknowledgments: The authors thank Angela Garve for her excellent technical help.

Conflicts of Interest: The authors declare no conflict of interest. 


\section{References}

1. Smith, J.M.; Haigh, J. The hitch-hiking effect of a favourable gene. Genet. Res. 2007, 89, 391-403. [CrossRef]

2. Kijas, J.W.; Lenstra, J.; Hayes, B.; Dalrymple, B. Genome-wide analysis of the world's sheep breeds reveals high levels of historic mixture and strong recent selection. PLoS Biol. 2012, 10, e1001258. [CrossRef]

3. Purfield, D.C.; McParland, S.; Wall, E.; Berry, D. The distribution of runs of homozygosity and selection signatures in six commercial meat sheep breeds. PLoS ONE 2017, 12, e0176780. [CrossRef]

4. Rochus, C.M.; Tortereau, F.; Plisson-Petit, F.; Servin, B. Revealing the selection history of adaptive loci using genome-wide scans for selection: An example from domestic sheep. BMC Genom. 2018, 19, 71. [CrossRef]

5. Ghasemi, M.; Zamani, P.; Vatankhah, M.; Abdoli, R. Genome-wide association study of birth weight in sheep. Animal 2019, 13, 1797-1803. [CrossRef] [PubMed]

6. Yurchenko, A.A.; Deniskova, T.; Yudin, N.; Reyer, H.; Wimmers, K.; Larkin, D. High-density genotyping reveals signatures of selection related to acclimation and economically important traits in 15 local sheep breeds from Russia. BMC Genom. 2019, 20, 294. [CrossRef] [PubMed]

7. Zhao, F.; McParland, S.; Du, L.; Berry, D. Detection of selection signatures in dairy and beef cattle using high-density genomic information. Genet. Sel. Evol. 2015, 47, 49. [CrossRef] [PubMed]

8. El-Halawany, N.; Zhou, X.; Al-Tohamy, A.; El-Sayd, Y.; Shawky, A.; Michal, J.; Jiang, Z. Genome-wide screening of candidate genes for improving fertility in Egyptian native Rahmani sheep. Anim. Genet. 2016, 47, 513. [CrossRef]

9. Burren, A.; Neuditschko, M.; Signer-Hasaler, H.; Flury, C. Genetic diversity analyses reveal first insights into breed-specific selection signatures within Swiss goat breeds. Anim. Genet. 2016, 47, 727-739. [CrossRef]

10. Kim, E.S.; Elbeltagy, A.; Aboul-Naga, A.; Rothschild, M. Multiple genomic signatures of selection in goats and sheep indigenous to a hot arid environment. Heredity 2016, 116, 255-264. [CrossRef]

11. McRae, K.M.; McEwan, J.; Dodds, K.; Gemmell, N. Signatures of selection in sheep bred for resistance or susceptibility to gastrointestinal nematodes. BMC Genom. 2014, 15, 637. [CrossRef]

12. Shrestha, J.N.B.; Vesely, J.A.; Chesnais, J.P. Genetic and phenotypic parameters for daily gain and body weights in Suffolk lambs. Can.J. Anim. Sci. 1985, 65, 575-582. [CrossRef]

13. Fitzmaurice, S.; Conington, J.; McHugh, N.; Banos, G. Towards future genetic evaluations for live weight and carcass composition traits in UK sheep. Small Rumin. Res. 2021, 196, 106327. [CrossRef]

14. Harvey, C.F.; Larry, A.K.; Richard, M.T.; Warren, M.S. Heritability and genetic correlations of feed intake, body weight gain, residual gain, and residual feed intake of beef cattle as heifers and cows. J. Anim. Sci. 2020, 98, skz394. [CrossRef]

15. Wei, C.H.L.; Liu, C.S. Encyclopedia of Modern Sheep Production Technology; Agriculture Press: Beijing, China, $2014 ;$ pp. 70-77.

16. Ptáček, M.; Ducháček, J.; Stádník, L.; Hakl, J.; Fantová, M. Analysis of multivariate relations among birth weight, survivability traits, growth performance, and some important factors in Suffolk lambs. Arch. Anim. Breed. 2017, 60, 43-50. [CrossRef]

17. Zamani, P.; Mohammadi, H. Comparison of different models for estimation of genetic parameters of early growth traits in the Mehraban sheep. J. Anim. Breed. Genet. 2008, 125, 29-34. [CrossRef] [PubMed]

18. Sallam, A.M.; Ibrahim, A.H.; Alsheikh, S.M. Estimation of genetic parameters and variance components of pre-weaning growth traits in Barki lambs. Small Rumin. Res. 2019, 173, 94-100. [CrossRef]

19. Abousoliman, I.; Reyer, H.; Oster, M.; Murani, E.; Wimmers, K. Analysis of candidate genes for growth and milk performance traits in the Egyptian Barki sheep. Animals 2020, 10, 197. [CrossRef] [PubMed]

20. Sallam, A.M. A missense mutation in the coding region of the toll-like receptor 4 (TLR4) gene affects milk traits in Barki sheep. Anim. Biosci. 2021, 34, 489-498. [CrossRef]

21. Weir, B.S.; Cockerham, C.C. Estimating f-statistics for the analysis of population structure. Evolution 1984, 38, 1358-1370. [CrossRef]

22. Zheng, X.; Levine, D.; Shen, J.; Laurie, C.; Weir, B. A high-performance computing toolset for relatedness and principal component analysis of SNP data. Bioinformatics 2012, 28, 3326-3328. [CrossRef]

23. Phipson, B.; Smyth, G.K. Permutation $p$-values should never be zero: Calculating exact $p$-values when permutations are randomly drawn. Stat. Appl. Genet. Mol. Biol. 2010, 9, 39. [CrossRef]

24. De Las Heras-Saldana, S.; Clark, S.A.; Duijvesteijn, N.; Gondro, C.; van der Werf, J.H.J.; Chen, Y. Combining information from genome-wide association and multi-tissue gene expression studies to elucidate factors underlying genetic variation for residual feed intake in Australian Angus cattle. BMC Genom. 2019, 20, 939. [CrossRef] [PubMed]

25. Shannon, P.; Markiel, A.; Ozier, O.; Baliga, N.S.; Wang, J.T.; Ramage, D.; Amin, N.; Schwikowski, B.; Ideker, T. Cytoscape: A software environment for integrated models of biomolecular interaction networks. Genome Res. 2003, 13, 2498-2504. [CrossRef]

26. Bindea, G.; Mlecnik, B.; Hackl, H.; Galon, J. ClueGO: A Cytoscape plug-in to decipher functionally grouped gene ontology and pathway annotation networks. Bioinformatics 2009, 25, 1091-1093. [CrossRef]

27. Marai, I.F.M.; Daader, A.H.; Bahgat, L.B. Performance traits of purebred Ossimi and Rahmani lambs and their crosses with Finnsheep born under two accelerated mating systems. Arch. Anim. Breed. 2009, 52, 497-511. [CrossRef]

28. Abd-Allah, M.; Abass, S.; Allam, F. Reproductive performance of Rahmani and Chios sheep and their lambs under Upper Egypt conditions. Online J. Anim. Feed Sci. 2011, 1, 121-129.

29. Thomson, B.C.; Muir, P.D.; Smith, N.B. Litter size, lamb survival, birth and twelve week weight in lambs born to cross-bred ewes. J. N. Z. Grassl. 2004, 66, 233-237. [CrossRef] 
30. Animal QTL Database-Animal Genome Databases. Available online: https://www.animalgenome.org/cgi-bin/QTLdb/OA/ ontrait?trait_ID=3228 (accessed on 29 July 2021).

31. Papaioannou, V.E. T-box genes in development: From hydra to humans. Int. Rev. Cytol. 2001, 207, 1-70. [CrossRef] [PubMed]

32. Gibson-Brown, J.J.; Agulnik, S.; Chapman, D.; Garvey, N.; Papaioannou, V. Evidence of a role for T-box genes in the evolution of limb morphogenesis and the specification of forelimb/hindlimb identity. Mech. Dev. 1996, 56, 93-101. [CrossRef]

33. Candille, S.I.; Chen, C.; Russ, A.; Barsh, G. Dorsoventral Patterning of the Mouse Coat by Tbx15. PLoS Biol. 2004, 2, e3. [CrossRef] [PubMed]

34. Carraro, L.; Ferrarasso, S.; Cardazzo, B.; Bargelloni, L. Expression profiling of skeletal muscle in young bulls treated with steroidal growth promoters. Physiol. Genom. 2009, 38, 138-148. [CrossRef] [PubMed]

35. Metodiev, S.; Young, J.; Onteru, S.; Rothschild, M.; Dekkers, J. A whole-genome association study for litter size and litter weight traits in pigs. Livest Sci. 2018, 211, 87-97. [CrossRef]

36. Pérez-Montarelo, D.; Madsen, O.; Alves, E.; Fernandez, A. Identification of genes regulating growth and fatness traits in pig through hypothalamic transcriptome analysis. Physiol. Genom. 2014, 46, 195-206. [CrossRef]

37. Firulli, A.B.; Miano, J.; Bi, W.; Johnson, A.; Schwarz, J. Myocyte enhancer binding factor-2 expression and activity in vascular smooth muscle cells. Association with the activated phenotype. Circ. Res. 1996, 78, 196-204. [CrossRef]

38. Iida, K.; Hidaka, K.; Takeuchi, M.; Yutani, C.; Morisaki, T. Expression of MEF2 genes during human cardiac development. Tohoku J. Exp. Med. 1999, 187, 15-23. [CrossRef]

39. Zhang, L.; Ma, X.; Xuan, J.; Wang, H.; Wu, M.; Du, L. Identification of MEF2B and TRHDE gene polymorphisms related to growth traits in a new Ujumqin sheep population. PLOS ONE 2016, 11, e0159504. [CrossRef]

40. HE Bo, Z.R.; Yuanzhu, X.; Hu, C. Culture, Identification and biological characteristics of skeletal muscle satellite cells of the Neonatal pig. Acta Vet. Zootech. Sin. 2006, 6, 555-559.

41. Chen, L.; Cheng, B.; Li, L.; Zhan, S.; Zhong, T.; Chen, Y.; Zhang, H. The molecular characterization and temporal-spatial expression of myocyte enhancer factor 2 genes in the goat and their association with myofiber traits. Gene 2015, 555, 223-230. [CrossRef]

42. Ahbara, A.; Bahbahani, H.; Almathen, F.; Agoub, M.; Mwacharo, J. Genome-wide variation, candidate regions and genes associated with fat deposition and tail morphology in Ethiopian indigenous sheep. Front. Genet. 2019, 9, 1-21. [CrossRef]

43. Farah, C.S.; Reinach, F.C. The troponin complex and regulation of muscle contraction. FASEB J. 1995, 9, 755-767. [CrossRef]

44. Bucher, E.A.; Maisonpierre, P.; Konieczny, S.; Emerson, C. Expression of the troponin complex genes: Transcriptional coactivation during myoblast differentiation and independent control in heart and skeletal muscles. Mol. Cell. Biol. 1988, 8, 4134-4142. [CrossRef] [PubMed]

45. Li, Y.; Chen, Y.; Li, J.; Wang, C.; Liu, X.; Ling, F.; Zhong, W. Molecular characterization, expression profile and polymorphisms of the porcine TNNC2 gene. Hereditas 2008, 145, 274-282. [CrossRef] [PubMed]

46. Xu, Q.; Kang, K.; Yan, F.; An, J.; Chen, Y. Characterization of the fast skeletal troponin C (TNNC2) gene in three Chinese native sheep breeds. Arch. Anim. Breed. 2008, 51, 572-581. [CrossRef]

47. Zhao, F.; Satoda, M.; Licht, J.; Hayashizaki, Y.; Gelb, B. Cloning and characterization of a novel mouse AP-2 transcription factor, AP-2delta, with unique DNA binding and transactivation properties. J. Biol. Chem. 2001, 276, 40755-40760. [CrossRef]

48. Moser, M.; Pscherer, A.; Roth, C.; Becker, J.; Fassler, R. Enhanced apoptotic cell death of renal epithelial cells in mice lacking transcription factor AP-2beta. Genes Dev. 1997, 11, 1938-1948. [CrossRef]

49. Tian-Ke, L.; Chun-Nian, L.; Xia, L.; Jie, P.; Xiao-Yun, W.; Min, C.; Wen, Q.; Ping, Y. GDF-10 Gene Polymorphism and Its Association with Production Traits in Gannan Yak. Sci. Agric. Sin. 2014, 47, 161-169. [CrossRef]

50. Pickering, N.K. Genetics of Flystrike, Dagginess and Associated Traits in New Zealand Dual-Purpose Sheep. Ph.D. Thesis, Massey University, Palmerston North, New Zealand, 2013.

51. Adoligbe, C.; Zan, L.; Farougou, S.; Wang, H.; Ujjan, J. Bovine GDF10 gene polymorphism analysis and its association with body measurement traits in Chinese indigenous cattle. Mol. Biol. Rep. 2012, 39, 4067-4075. [CrossRef]

52. Hong, E.P.; Park, J.W. Sample Size and Statistical Power Calculation in Genetic Association Studies. Genom. Inform. 2012, 10, 117-122. [CrossRef] [PubMed] 